\title{
Artikel
}

\section{Femicide: een kritische reflectie op het gebruik van de term}

Prof. dr. M.C.A. (Marieke) Liem*

\section{Inleiding}

In maart 2020 steekt de 47-jarige Freddie V. zijn 46-jarige vriendin neer bij een geldruzie. Ze overlijdt in het ziekenhuis. In december datzelfde jaar schiet in Velserbroek een 61-jarige man met een geweer zijn 59-jarige vrouw dood, waarna hij zich suïcideert. ${ }^{1}$ In mei 2021 wordt een 28-jarige vrouw om het leven gebracht. Haar vriend, die volgens getuigen onder invloed was van cocaïne, wordt aangehouden. ${ }^{2}$

In toenemende mate worden dergelijke zaken geduid als femicide, breed gedefinieerd als het doden van vrouwen om hun gender. ${ }^{3}$ Deze term werd in de eerste instantie in gebruik genomen door organisaties en activisten die zich inzetten voor vrouwenrechten, om aandacht te vragen voor geweld tegen vrouwen. In deze definitie staat het idee centraal dat vrouwen door mannen worden gedood om hun vrouw-zijn, als manifestatie van een combinatie van mannelijke haat tegen vrouwen, historische ongelijkheid tussen mannen en vrouwen, en het beschouwen van vrouwen als mannelijk eigendom. ${ }^{4}$ Het juridisch gebruik van de term femicide is relatief nieuw,

Marieke Liem is hoogleraar Sociale Veerkracht en Veiligheid aan de Universiteit Leiden.

1 G. Leistra, 'Aantal moorden in 2020 licht gestegen' Elsevier 14 januari 2021.

2 NOS 'Verdachte moord op vriendin in Volendam onder invloed van cocaïne', via nos.nl/artikel/2381251-verdachte-moord-op-vriendin-involendam-onder-invloed-van-cocaine.

3 Report of the Secretary-General, In-depth study on all forms of violence against women, p. 41 en p. 31, 30 april 2006, A/61/122/Add.1.

4 J. Radford en D. Russell (red.), Femicide: The politics of woman killing, Buckingham: Open University Press 1992. en heeft zijn zwaartepunt in Latijns-Amerikaanse landen, waar femicide in de afgelopen twee decennia als apart crimineel vergrijp in nationale wetgeving is opgenomen. ${ }^{5}$ In Nederland is het gebruik van de term vooralsnog beperkt tot de media, en tot internationale organisaties die zich onder andere met vrouwenrechten bezighouden. Het gebruik van deze term telt talloze voordelen: zo wordt aandacht gegenereerd voor geweld tegen vrouwen, aandacht voor de voortdurende en diepgewortelde genderongelijkheid in de samenleving, en zo kan Nederland meebewegen en participeren in de internationale femicidebeweging. De toegenomen wereldwijde belangstelling voor het fenomeen en toepassing van de term, waaronder in Nederland, heeft tevens voor een inflatie van de term gezorgd - hetgeen de preventie van geweld tegen vrouwen niet louter goed doet.

\section{Bruikbaarheid van de term femicide}

In de eerste plaats zorgt de brede definitie, gecombineerd met de politieke, niet zelden activistische achtergrond waartegen de term gebruikt wordt, voor problemen. Een parapluterm als femicide laat zich niet gemakkelijk vertalen naar wetgeving, onderzoek of beleid. $\mathrm{Na}$ het benoemen en gebruiken van de term, classificeren sommige - met name Latijns-Amerikaanse - landen vrijwel alle moorden op vrouwen als femicides, terwijl andere landen geen enkele femicidezaak lijken te kennen. Zo werden illegale abortussen met dodelijke afloop, Mexico, Nicaragua, Panama, Paraguay, Peru, Uruguay, en Venezuela. 
moderne dodelijke heksenjacht, en het doden van vrouwen in de context van mensensmokkel elk als femicide bestempeld. ${ }^{6}$ Weer andere landen en instituties zien alleen partnerdoding van vrouwen door hun mannelijke (ex-)partners als "echte" femicide, al dan niet gepaard gaand met eerdere bedreiging, stalking of geweld. ${ }^{7} \mathrm{Te}-$ gelijkertijd zien we bij dergelijke (ex-)partnerdodingen ook dat de dader geen specifiek misogynistisch motief heeft. Dit maakt het moeilijk om de aard en omvang van fataal geweld tegen vrouwen te kunnen inschatten: wanneer we niet precies weten wat we onder femicide verstaan, hoe kunnen we het dan meten?

Het grootste bezwaar van het gebruik van de term is echter gelegen in de kern van de eerdergenoemde definitie: wanneer kunnen we vaststellen of een vrouw werd gedood om haar gender? Jarenlang moordonderzoek, zowel in Nederland als daarbuiten, heeft ons laten zien dat een scala aan facetten een rol speelt bij moord of doodslag, de belangrijkste daarvan zijn wellicht de relatie tussen dader en slachtoffer en het motief. Zo worden vrouwen onder andere gedood in de context van uit de hand gelopen burenruzies, als tragische afloop van een beroving, als kind door een psychotische, laagbegaafde of rancuneuze ouder, of als prostituee door een gewelddadige klant. En ja, ook worden vrouwen gedood door hun huidige of voormalige mannelijke partner. Ons langlopende Nederlandse moordonderzoek laat zien dat partnerdoding in de afgelopen 25 jaar zo'n 52 procent van alle dodingen van vrouwen betrof. ${ }^{8}$ Andere typen moord op vrouwen betroffen kinderdoding (10\%), overige familiedoding (11\%), dodelijke overvallen (11\%), dodelijke berovingen (7\%), en in mindere mate seksuele doding en dodelijke ruzies in het uitgaansleven. In diepgaand vervolgonderzoek naar partnerdoding hebben we voorts kunnen vaststellen dat in 39\% de mannelijke dader eerder gewelddadig was ten opzichte van het vrouwelijke slachtoffer in de zaak. ${ }^{9}$ Met andere woorden: wat intuïtief, bij gebrek aan een passende definitie, als femicide wordt gezien (ofwel: partnerdoding van vrouwen in de context van langdurig geweld), blijkt bij nader inzicht slechts een onderdeel van een heterogeen palet met verschillende relaties tussen dader en slachtoffer en verschillende onderliggende motieven. Wanneer we naar wereldwijde statistieken kijken, liggen de cijfers nog verder uiteen dan in Nederland: zo laten UNODC-data zien dat van alle vrouwelijke moordslachtoffers ter wereld, jaarlijks een derde (34\%) door hun (ex-)partner wordt gedood; 24\% door overige familieleden (denk hierbij aan kinderdoding), en $42 \%$ door

6 UN Women, 'Analysis of femicide / feminicide legislation in Latin America and the Caribbean and a proposal for a model law' New York: UN Women 2018.

7 M. Dawson en M. Carrigan, 'Identifying femicide locally and globally: Understanding the utility and accessibility of sex/gender-related motives and indicators', Current Sociology 2020/69, 5, p. 682-704.

8 M. Liem en P. Aarten, Dutch Homicide Monitor 1992-2019, Leiden: Universiteit Leiden.

9 P. Aarten, C. Boelema, L. Alink, en M. Liem, 'Wanneer blaffende honden bijten. Een vergelijking tussen fataal en niet-fataal huiselijk geweld', Den Haag: Universiteit Leiden 2019. niet-familieleden. ${ }^{10}$ Het klakkeloos toepassen van de term femicide op al deze zaken doet dus geen recht aan de heterogeniteit aan moorden waarin vrouwen het slachtoffer worden. Wanneer we deze dynamiek toepassen op mannelijke slachtoffers, zouden we de term viricide (vir: man, -cide: doden) nieuw leven in moeten blazen, in brede zin verwijzend naar geweld waar mannen disproportioneel vaak het slachtoffer van zijn vanwege klassieke genderpatronen in de samenleving. Daarmee zouden we eveneens voorbijgaan aan de diversiteit van zaken waarin mannen worden gedood, variërend van uitgaansruzies, burenruzies, conflicten in het criminele circuit, familievetes, en ja, ook dodelijke ruzies waarin zij het slachtoffer worden van hun vrouwelijke partner.

\section{Tot besluit}

Ondanks deze definitiekwesties erken ik het nut van het in het leven roepen van een term zoals femicide om politieke aandacht te vragen voor een prangend probleem, en om misogynistische opvattingen en uitlatingen te benoemen en de kop in te drukken. In gebieden zoals Latijns-Amerika is het gebruik van de term een krachtige tool om onzichtbaar geweld tegen vrouwen, binnenshuis én buitenshuis, zichtbaar te maken. Geweld waar vele vrouwen wereldwijd dagelijks mee te maken krijgen, is een ernstige bedreiging voor de volksgezondheid én een schending van mensenrechten. ${ }^{11}$ Echter, het wetenschappelijk, juridisch en beleidsmatig reduceren van moord op vrouwen door hun vrouw-zijn, en de eenzijdige focus op slechts één type moord (namelijk: langdurige mishandeling van vrouwen door hun mannelijke (ex-)partners, eindigend in partnerdoding ${ }^{12}$ ) doet geen recht aan de heterogene contexten waarin vrouwen - en mannen - worden gedood.

Om tot adequate preventiemaatregelen te komen, en om hier passend beleid op te ontwerpen, dienen we eerst duidelijk voor ogen te hebben wat we precies willen voorkomen: structureel geweld tegen vrouwen in de breedste zin van het woord? Dodelijk geweld tegen vrouwen in de context van mensensmokkel en prostitutie? Dodelijke mishandeling van eigen (stief)dochters? Of structureel huiselijk geweld, stalking of bedreiging waarin een hoog risico op een dodelijke afloop bestaat? Laten we het probleem dan specificeren, en spreken van respectievelijk prostitutiedoding, kinderdoding of partnerdoding. Het klakkeloos overnemen, zowel in de wetenschap, door de wetgever, als in beleidsvorming, van een parapludefinitie uit een Latijns-Amerikaanse context komt het gedegen wetenschappelijk onderzoek, en vervolgens het formuleren van preventiemogelijkheden, niet ten goede. Met het helder afbakenen van het feno-

UNODC, Global Study on Homicide. Gender-related killing of women and girls, Vienna: United Nations 2018.

11 N. Ridder, 'Geweld tegen vrouwen stopt niet vanzelf', NRC 1 juli 2021.

12 Dawson en Carrigan 2020. 
meen, het verzamelen en gebruiken van solide gegevens, kunnen we geweld tegen vrouwen in diverse maatschappelijke contexten beter begrijpen, en aan de hand daarvan adequate, datagedreven preventiemaatregelen ontwikkelen. 